Original Paper http://ajol.info/index.php/ijbcs http://indexmedicus.afro.who.int

\title{
Contribution of sacred forests to biodiversity conservation: case of Adjahouto and Lokozoun sacred forests in southern Benin, West Africa
}

\author{
Ismaïla TOKO IMOROU ${ }^{1,4^{*}}$, Ousséni AROUNA ${ }^{1,2,4}$, Laurent G. HOUESSOU ${ }^{3,4}$ and \\ Brice SINSIN ${ }^{4}$ \\ ${ }^{I}$ Laboratory of Cartography (LaCarto) / University of Abomey-Calavi (UAC), 10 PO Box 1082 Cotonou- \\ Houeyiho, Benin. \\ ${ }^{2}$ School of Building and Road Sciences and Technologies (ESTBR),National University of Sciences, \\ Technologies, Engineering and Mathematics (UNSTIM), PO Box 2282 Abomey, Benin. \\ ${ }^{3}$ National School of Wildlife and Protected Areas Management (ENSAGAP)/ University of Parakou, PO Box \\ 1967 Abomey-Calavi, Benin. \\ ${ }^{4}$ Laboratory of Applied Ecology (LEA) / University of Abomey-Calavi (UAC), PO Box 1974 Cotonou, Bénin. \\ ${ }^{*}$ Corresponding author; E-mail: ismael_toko@yahoo.fr
}

\section{ACKNOWLEDGEMENTS}

The authors are grateful for local forests management support project (PAGEFCOM) that funded this research.

\section{ABSTRACT}

In the current context of the rapid changes of land cover and land use in Benin, sacred forests are thought to be sanctuaries of biodiversity and representative of primary vegetation. In order to assess the contribution of sacred forests to phytodiversity conservation, this study was carried out in Adjahouto and Lokozoun sacred forests located in the southern region of Benin. Phytosociological relevés were done in 25 circular plots of $18 \mathrm{~m}$ radius. Based on the species red list of Benin, threatened species found in Adjahouto and Lokozoun sacred forests were identified. Moreover, socio-economic survey of local residents allowed highlighting the factors that could impede the contribution of sacred forests in biodiversity conservation. Regarding plant diversity, a total of 75 species (68 tree species and 7 herbaceous species) distributed in 70 genera and 40 families were determined in the sacred forests of Adjahouto and Lokozoun. The plant communities Shannon diversity index ranged from 2.64 to 3.26 bits. The proportion of endangered species represented $8 \%$ in the Adjahouto sacred forest and $12 \%$ in the Lokozoun sacred forest. Phanerophytes were the dominant life forms in the two sacred forests. The Guineo-Congolese species were the most abundant (50\% in Adjahouto and $41.38 \%$ in Lokozoun) and the most dominant (46.54\% in Adjahouto and $90.27 \%$ in Lokozoun). The chorotype compositions showed that the Adjahouto and Lokozoun sacred forests still keep their primary vegetation and thereby enhance the global biodiversity conservation in Benin.

(C) 2017 International Formulae Group. All rights reserved.

Keywords: Biodiversity, phytosociology, conservation, threatened species, sacred forests, Benin. 


\section{INTRODUCTION}

In situ conservation is one of biodiversity conservation strategies that is widely recommended by the Convention on Biological Diversity (CBD) in the current context of rapid and widespread degradation of the environment (Kokou et al., 2005; Toko Imorou, 2008; Djogbenou et al., 2011; Arouna et al., 2011, Djego et al., 2011; Amoussou et al., 2016). In Benin Republic, protected areas including national parks, gazetted forests and reforestation perimeters were created for biodiversity conservation. These protected areas represent $25 \%$ of the total land area (Sinsin et al., 2010). For the sustainable conservation of these protected areas, management plans were developed and implemented. Despite the ongoing management plans, the protected areas are still facing human disturbance involving biodiversity degradation (Djogbenou, 2010).

Until recently, community forests such as sacred forest are neglected by the national policy forest conservation despite their importance in biodiversity conservation. However, since the meeting on "the sacred and environment" organized by UNESCO in Paris at the Tenth World Forestry Congress in 1991, great attention was paid to the contribution of the sacred forests in biodiversity conservation. Sacred forests are traditionally preserved from human actions in respect to the tradition and the fear of the deities hosted by these forests. Sacred forests are then protected by endogenous religions practices. According to Djogbenou et al. (2016), sacred forests represent the samples of natural vegetation and shelter many rare plant species. In Benin, FAO (2010) estimated the number of sacred forests to 2940 with 18,360 hectares representing $0.16 \%$ of the national territory. Previous studies already reported the socio-cultural and ecological importance of sacred forests in Benin (Sokpon and Ago, 2001; Kokou and Sokpon, 2006; Ehinnou Koutchika et al., 2013, Ehinnou Koutchika et al., 2014, Arouna et al., 2017). They provide many ecosystem services to local population. For instance, they play the role of living laboratory for scientific studies and represent the refuge and sanctuary of biodiversity, primary ecosystem and genetic pool (OIBT, 2012; Ehinnou Koutchika et al., 2014a). Moreover, these sacred forests also shelter many medicinal plants, threatened plant species and several fruit trees that attract birds and wild animals (PIFSAP, 2012). Despite their importance, very little researches assessed the contribution of sacred forests to biodiversity conservation. Nowadays, it becomes urgent to fill this gap of information since the sacred forests are facing to degradation due to population growth and intensification of human activities such as agriculture, charcoal production, the marketing of non-timber forest products and wildfires (Sokpon and Agbo, 2010; Diatta et al., 2017). Therefore, quantitative data on the ecological and floristic potentialities may help to increase our knowledge on the crucial role played by the sacred forests in local biodiversity conservation and designing sustainable strategies for their conservation. Through this study, we focused on the specific case of the sacred forests of Adjahouto and Lokozoun in the southern Benin to make available quantitative data on their floristic potentiality in order to provide forest managers and decision makers reliable data for the sustainable conservation of sacred forests in Benin. The main objective of the study is to assess the contribution of sacred forests in the conservation of plant biodiversity. Specifically, its aims at determining the floristic composition of two sacred forests in the southern Benin and to assess the natural stand structure in forests.

\section{MATERIALS AND METHODS}

\section{Study area}

The present study was carried out in Adjahouto and Lokozoun sacred forests in the 
southern region of Benin (Figure 1). The Adjahouto sacred forest with an area of 2.57 ha is located in the village of Adjadji Bata, in the District of Allada (Atlantic Department). The Lokozoun sacred forest with an area of 6.10 ha is located in the village of Satre, in the District of Tori-Bossito, (Atlantic Department).

The two sacred forests are located in a region with a subequatorial climate. The annual rainfall ranges from 1100 to $1300 \mathrm{~mm}$ with two rainy seasons (one long from midMarch to mid-July and one short from midSeptember to mid-November) alternating with two dry seasons (one large from midNovember to mid-March and one short from mid-July to mid-September) (Adams et Boko, 1983). The dominant soils in the region are ferralitics. The two studied forests belong to the Guinean-Congolese region originally composed of moist semi-deciduous forests. Based on the phytogeographical districts (Adomou et al., 2006), the sacred forests of Adjahouto and Lokozoun are located in the District of Plateau. Local populations of these forests mainly practice agriculture and charcoal production. Nowadays, degradation indices such as illegal logging of wood are observed despite the sacred status of these forests.

\section{Data collection}

\section{Vegetation data collection}

The vegetation data collection was carried out through phytosociological relevés using Braun-Blanquet method (Weber et al., 2000). A total of 25 circular plots were installed in both sacred forests. For the herbaceous layer, we used circular plots of 5 $\mathrm{m}$ radius while for the tree layer, circular plots of $18 \mathrm{~m}$ radius were used. Inside each plot, we collected: (i) exhaustive species list, (ii) abundance dominance coefficient for each species based on Braun Blanquet coefficient. The species were identified by comparing the collected specimen with those of the National Herbarium of Benin or from other Flora
(Hutchinson and Dalziel, 1954-1972; Akobundu and Agyakwa, 1989; Arbonnier, 2002; Akoegninou et al., 2006; de Souza, 2008). The nomenclature of Hutchinson and Dalziel (1954-1972) and Lebrun and Storck (1991-1997) were used. For each recorded species, the corresponding life form was determined following Raunkiaer (1934). Species chorological types were determined following the chorological subdivisions of White (1986). We refer to the Nature Conservation in the West Africa: Red List for Benin (Neuenschwander et al., 2011) to determine the endangered species in each forest.

In addition to phytosociological relevés, tree measurement was carried out in the same plots. The diameter at the breast height of each tree was measured by using forest compass. The height of dominant species was determined in each plot with clinometer. The regeneration (individuals with $1 \mathrm{~cm} \leq$ diameter $<10 \mathrm{~cm}$ ) was counted in circular plots of $5 \mathrm{~m}$ radius.

\section{Socio-cultural data collection}

Socio-cultural data were collected using questionnaires and interview guide. Informants are the dignitaries of sacred forests and farmers whose fields are closed to Adjahouto and Lokozoun sacred forests. Individual interviews with 45 persons and two focus group were done. Questions asked during the survey were related to ethnobotanical used of the sacred forest resources, endogenous strategies used to manage these sacred forests, main stakeholders involved in the forest conservation as well as the direct and indirect determinants of these forests degradation.

\section{Data analysis}

\section{Vegetation data analysis}

Vegetation composition was assessed by counting the number of species (species richness), genera and families for the herbaceous and wood species. The most represented families and the dominant species 
were determined for each forest. Besides, the Importance Value Index (IVI) of species was calculated using the following formula:

$\mathrm{IVI}=\mathrm{RD}+\mathrm{FR}+\mathrm{RC}$ where $\mathrm{RD}$ is the relative density, FR the relative frequency and $\mathrm{RC}$ the relative cover of the species.

Alpha diversity ( $\alpha$-diversity) was used to estimate the intra-community diversity of the plant communities (Magurran, 2004). In this study, the species richness per plot, the Shannon diversity index (Shannon, 1949) and the Pielou evenness (Pielou, 1969) were used to assess the $\alpha$-diversity of the plant communities.

Species richness per plot (R) was determined by counting the number of species recorded in the relevés done in each forest.

Shannon diversity index $(\mathrm{H})$ was calculated using the following formula $\mathrm{H}=-\Sigma$ $\mathrm{P}_{\mathrm{i}} \log _{2} \mathrm{P}_{\mathrm{i}}$ where $\mathrm{P}_{\mathrm{i}}=\left(\mathrm{n}_{\mathrm{i}} / \mathrm{N}\right)$ is the relative frequency of individuals of the species (i) with $\mathrm{n}_{\mathrm{i}}$ the number of individuals per species and $\mathrm{N}$ the total number of individuals.

Pielou evenness (E) was evaluated through the following formula $E=H / \log _{2} R$ where $(R)$ is the species richness, $\log _{2} R$ the theoretical value of the maximum achievable diversity in each group.

Jaccard similarity index (IJ) was calculated to compare the floristic composition of the two sacred forests.

$\mathrm{IJ}=\mathrm{c} \times 100 /(\mathrm{a}+\mathrm{b}-\mathrm{c})$; where $\mathrm{c}$ is the number of species common to both sacred forests; $a$ is the number of species recorded in Adjahouto sacred forest and $b$ the number of species recorded in Lokozoun sacred forest. We assumed that if $\mathrm{IJ} \geq 50 \%$, the two sacred forests were floristically similar.

\section{Life forms, chorotype and threatened species composition}

Life forms and chorotype composition of the forest were determined through the computation of the abundance and percentage cover of each life form and chorotype. The relative abundance of the threatened species in each forest was also determined.

\section{Tree population structural parameters}

The tree density and the basal area were calculated to assess the sacred forests population demography.

The tree density (D, stems ha ${ }^{-1}$ ) was calculated using the following formula:

$\mathrm{D}=\mathrm{N} / \mathrm{S}$ where $\mathrm{N}$ is the number of trees with diameter at the breast height $(\mathrm{dbh}) \geq 10 \mathrm{~cm}$ and $\mathrm{S}$ inventoried area in hectare.

The density of regeneration (Dr, individuals.ha ${ }^{-1}$ ) was calculated using the following formula:

Dr $=\sum \mathrm{y}_{\mathrm{i}} / \mathrm{S}$ where $\mathrm{y}_{\mathrm{i}}$ is the number of individuals $(1 \mathrm{~cm} \leq$ diameter $<10 \mathrm{~cm})$ of the species $\mathrm{i}$ and $\mathrm{S}$ the inventoried area in hectare.

The basal area $\left(\mathrm{G}_{\mathrm{i}}, \mathrm{m}^{2} \mathrm{ha}^{-1}\right)$ was calculated using the following formula:

$\mathrm{G}_{\mathrm{i}}=\Sigma \Pi \mathrm{d}_{\mathrm{i}}^{2} \mathrm{x} / 4 \mathrm{~S}$ where $\mathrm{d}_{\mathrm{i}}$ is the tree diameter (m); $\mathrm{S}$ the inventory area in hectare.

Mann Whitney test was used to compare the mean value of structural parameters between sacred forests with Minitab 14.0 statistical Software.

\section{Socio-cultural data analysis}

Informants' opinions on the use of the forest resources and factors contributing to the forest degradation were analyzed by calculating the citation frequency for each quoted modality. The frequency was estimated as follow $F=\left(n_{\mathrm{i}} / \mathrm{N}\right) \times 100$ where $\mathrm{n}_{\mathrm{i}}$ is the number of informants who gave positive answer to a given modality and $N$ the total number of informants. The monitoring-circle was used to assess factors which can affect the sacred forest contribution to biodiversity conservation. The information gathered during the focus group helped to better understand the endogenous management modes of sacred forests and the factors that may adversely affect the contribution of these sacred forests to biodiversity conservation. 


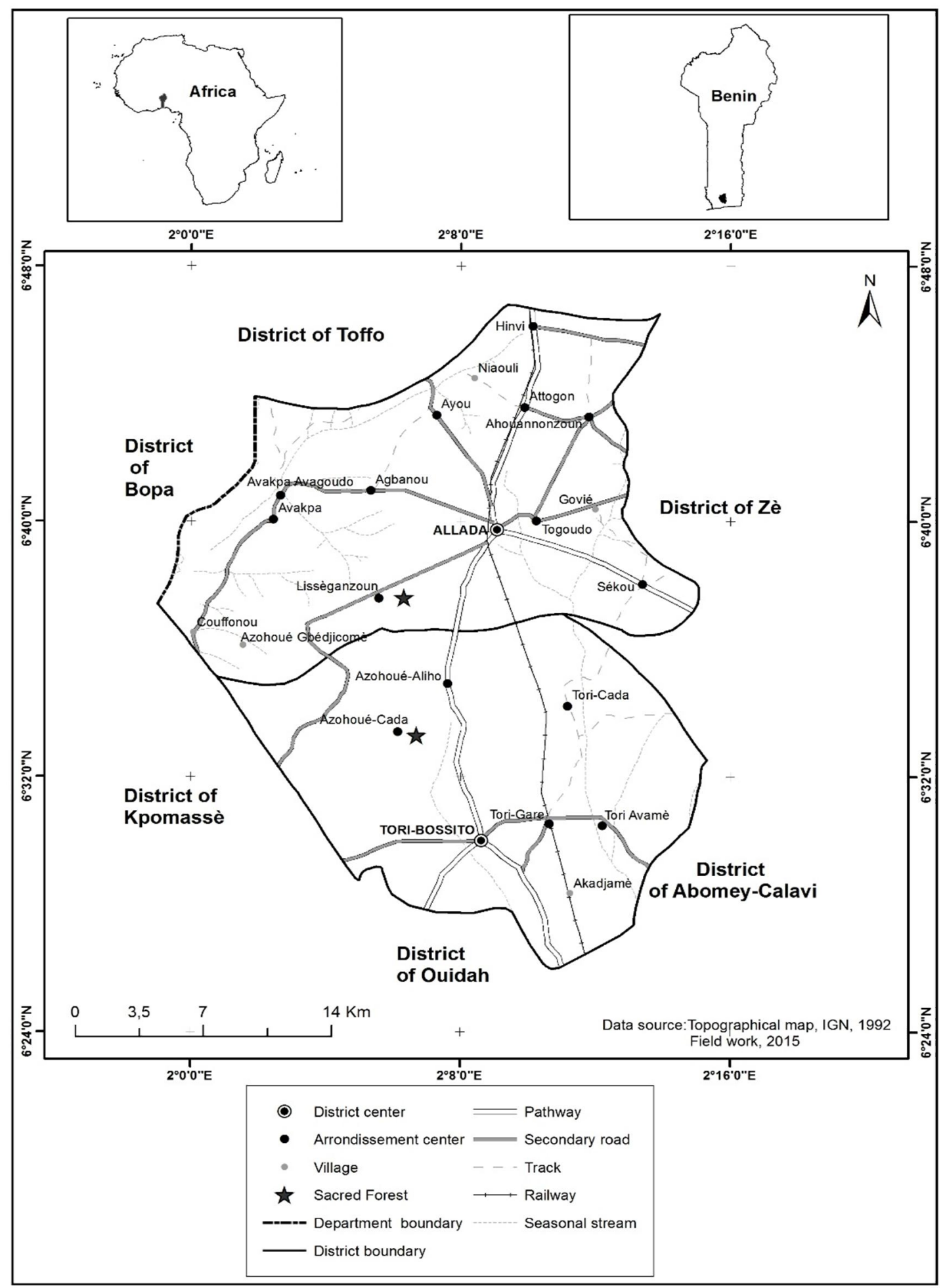

Figure 1: Localization of study area 


\section{RESULTS}

\section{Forest diversity}

In Adjahouto sacred forest, 52 plant species including 48 trees and 4 herbaceous species belonging to 51 genera and 27 families were inventoried (Table 1). The most represented families were: Fabaceae $(13 \%)$, Apocynaceae (8\%), Euphorbiaceae $(8 \%)$ and Moraceae (8\%). The dominant species were Cola millenii and Trichilia prieureana. The most important species (IVI $\geq 10 \%$ ) were Cola millenii (37.59\%), Milicia excelsa (25.98\%), Albizia zygia (23.78\%), Holoptelea grandis (22.55\%), Delonix regia (19.83\%), Ceiba pentandra (18.72\%), Lecaniodiscus cupanioides (16.21\%), Trichilia prieureana (15.66\%), Sterculia tragacantha (13.52\%), Dialium guineense (13.16\%), Hura crepitans $(10.50 \%)$ and Pandanus candelabrum (10.50\%).

In Lokozoun sacred forest, 69 plant species (64 trees and 5 herbaceous) belonging to 62 genera and 33 families were inventoried (Table 1). The most represented families were: Fabaceae (14\%), Euphorbiaceae (10\%), Moraceae (6\%), Sapindaceae (6\%) and Sterculiaceae $(6 \%)$. The dominant species were Teclea verdoorniana and Trichilia prieureana. The most important species (IVI $\geq 10 \%)$ were Antiaris toxicaria (43.87\%), Holoptelea grandis (38.88\%), Trichilia prieureana (35.47\%), Strophanthus hispidus (28.20\%), Lecaniodiscus cupanioides (24.07\%), Ceiba pentandra (20.68\%), Dialium guineense (13.66\%) and Psychotria psychotrioides $(11.10 \%)$.

The mean species richness (Figure 2A) was $20 \pm 4$ per 0.1 ha in Adjahouto sacred forest differed significantly from the mean species richness $(17 \pm 5)$ per 0.1 ha in Lokozoun sacred forest ( $p$ value $=0,029$ ). The Shannon Diversity Index values ranged from 3 to 3.6 bits in Adjahouto's sacred forest, while it ranged from 2.3 to 3.1 bits in the sacred Lokozoun Forest (Figure 2B). Pielou evenness varied from 0.87 to 0.94 in the Adjahouto sacred forest and from 0.76 to 0.88 in the sacred Lokozoun forest (Figure 2C).
Jaccard index is 0.21 showing that the two sacred forests were floristically different.

\section{Life forms and phytogeographic types}

Overall, the phanerophytes were the most important life form (Figure 3). However, we observed some herbaceous and lianas in these forests showing their relative disturbance. In Adjahouto forest, phanerophytes yielded $92.68 \%$ as abundance and $94.75 \%$ as cover for the life forms. In this forest, the phanerophytes were represented by mesophanerophytes (abundance: 26.83\%; cover: $22.57 \%$ ), microphanerophytes (abundance: $24.39 \%$; cover: $20.73 \%$ ) and nanophanerophytes (abundance: 17.07\%; cover: $31.23 \%$ ). The herbaceous (abundance: $7.32 \%$; cover: $5.25 \%$ ) were very weakly found in this forest. The absence of annual plants such as therophytes in the Adjahouto sacred forest is a stability indicator.

In the Lokozoun sacred forest, the phanerophytes (abundance: 87.50\%; cover: 94.97\%) especially mesophanerophytes (abundance: 27.50\%; cover: 5.47\%), microphanerophytes (abundance: 17.50\%; cover: $47.05 \%$ ) and megaphanerophytes (abundance: 15\%; cover: $35.45 \%$ ) are the most dominant. In this ecosystem, except chamaephytes (abundance: $7.50 \%$; cover: $1.75 \%$ ), annual and perennial grasses were absent; reflecting the stability of this forest.

Regarding the chorotypes composition of the forest (Figure 4), the proportion of Guineo-Congolese species (abundance: 50\%; cover: $46.54 \%$ ) and continental distributed species (Sudano-Guinean, Afro-Malagasy, Afro-tropical, African Pluri-regional) (abundance: $33.33 \%$; cover: $48.40 \%$ ) showed that the flora of the Adjahouto sacred forest still kept its phytogeographical affinity to the region. Furthermore, the wide distributed species (Pantropical, Paleotropical, Afroamerican) in this forest (abundance: 16.67\%; cover: $5.05 \%$ ) can be interpreted as an indicator of an early degradation of this sacred forest.

In the Lokozoun sacred forest, the high proportion of Guineo-Congolese species 
(abundance: $\quad 41.38 \%$; cover: $\quad 90.27 \%$ ) demonstrated the specificity of the flora and primary vegetation conservation of this sacred forest. Guineo-Congolese species were followed by continental distributed species (Sudano-Guinean, Afro-Malagasy, Afrotropical) (abundance: 37.93\%; cover: 5.53\%). The low proportion of wide distribution species (abundance: 20.69\%; cover: 4.20\%) could be interpreted as an indicator of low degradation of this sacred forest. In that sacred forest, $60 \%$ of species belonged to taxa of primary forests.

\section{Tree population structural parameters}

The tree density (Figure 5A) and basal area (Figure 5B) in the Adjahouto sacred forest were respectively $189.22 \pm 35 \mathrm{stems} /$ ha and $18.70 \pm 7.64 \mathrm{~m}^{2} / \mathrm{ha}$. The highest tree of this sacred forest was Milicia excelsa and measured $28 \mathrm{~m}$. The average density of regeneration (Figure 5C) of wood stands was $1431.82 \pm 318.20$ individuals $\mathrm{ha}^{-1}$. In the Lokozoun sacred forest, tree density (Figure 5A) and basal area (Figure 5B) were respectively $174.47 \pm 37$ stems ha $^{-1}$ and 12.93 $\pm 5.71 \mathrm{~m}^{2} \mathrm{ha}^{-1}$. The highest tree of this sacred forest was Cola cordifolia and measured 24 $\mathrm{m}$. The density of regeneration (Figure 5C) of wood strands was $2450 \pm 859.29$ individuals $\mathrm{ha}^{-1}$. However no significant differences were found between the forest structural parameters (tree density, basal area and regeneration density; $p$ value $>0.05$ ).

\section{Contribution of sacred forest to rare species conservation}

The sacred forests of Adjahouto and Lokozoun include respectively $8 \%$ (4 of 52 inventoried species) and $12 \%$ (8 of 69 inventoried species) of rare plant species from the Red List species for Benin (Table 2). The high proportion of phanerophytes, GuineoCongolese species, Continental distributed species and the presence of many threatened species in these sacred forests clearly demonstrated the contribution of these forests to biodiversity conservation.

\section{Local communities' perception of the sacred forests degradation}

Three factors including the functioning of the sacred forest local committee, the types of divinities and wind (Figure 6) were quoted by local populations as the main drivers that contributed to the sacred forests conservation.

As well, the dynamism of the management committee helped preserving the sacred forests against wildfires, wood logging and uncontrolled harvesting of medicinal plants. In fact, this committee was involved in local population awareness raising and different activities implementation in the forest such firebreak, enrichment, etc. However, the malfunctions of the management committee were reported as the main hindrance which could significantly reduce conservation efforts of the sacred forest.

Regarding the types of divinities, local population estimated that the more demanded was the divinity, the more the forest was conserved. Thus, divinities that restricted forest access to certain categories of the population (women, uninitiated, etc.) and at a given periods contributed highly to lessen pressure on these forests. The most feared divinities are those which give the bad luck or death to the one who violated the divinities prescription. Among these divinities «Oro » is most commonly cited.

According to the population, violent gust of wind degrade the forests by uprooting large trees and creating gaps through the canopy that modify the forests physiognomy.

Finally, populations opined that factors such as sociocultural origin, forest size, illegal logging and wildfires do not have a great impact on the conservation of sacred forests (Figure 6). 
Table 1: Floristic composition of Adjahouto and Lokozoun sacred forests.

\begin{tabular}{lllll}
\hline Forest & Diversity & Herbaceous & Trees & Overall \\
\hline \multirow{3}{*}{ Adjahouto } & Species richness & 4 & 48 & 52 \\
& Number of Genera & 3 & 48 & 51 \\
& Number of family & 3 & 24 & 25 \\
\multirow{4}{*}{ Lokozoun } & Species richness & 5 & 64 & 69 \\
& Number of Genera & 5 & 57 & 62 \\
& Number of family & 5 & 28 & 33 \\
\hline
\end{tabular}
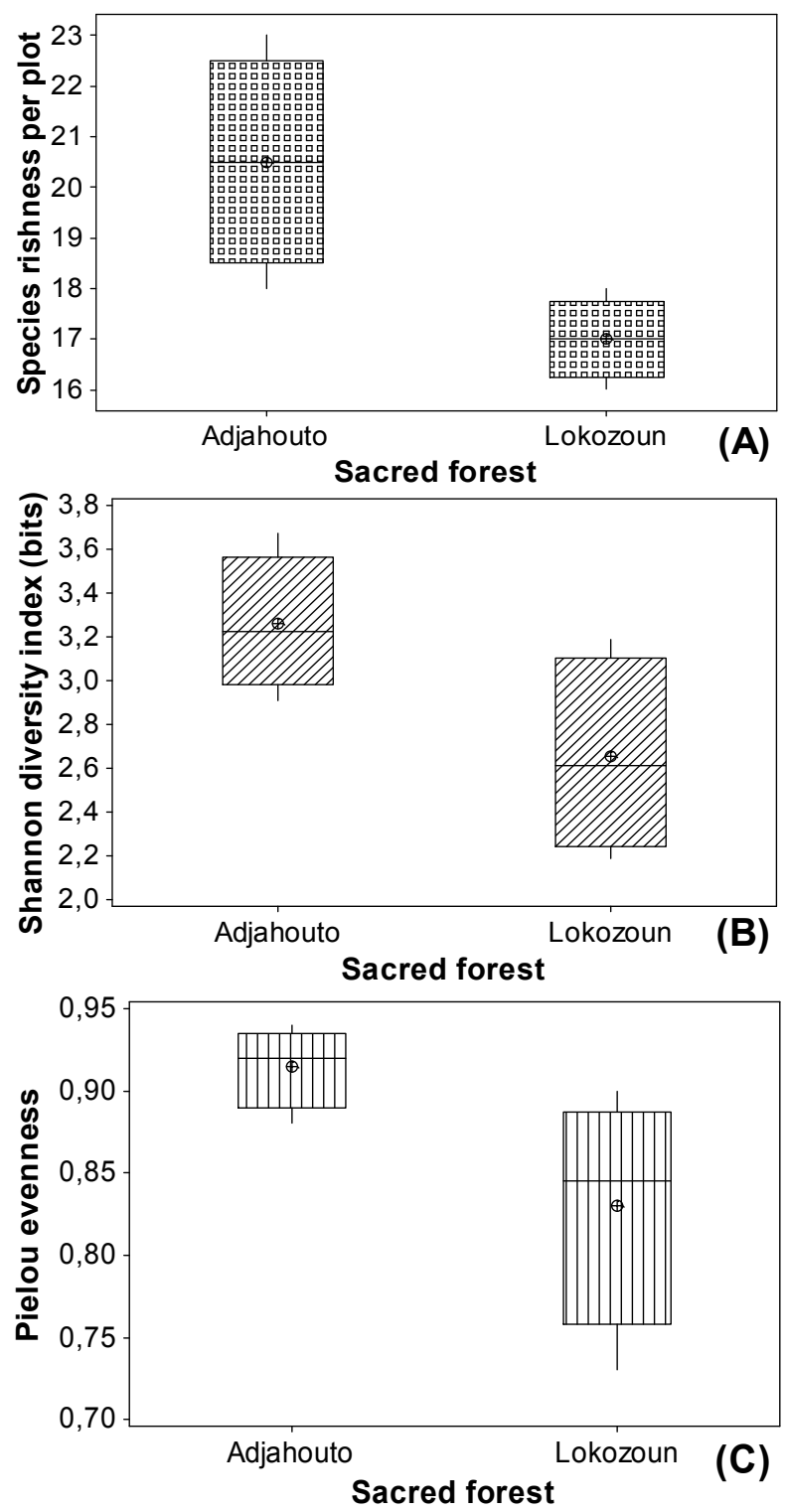

Figure 2: Variation of species richness per plot (A), Shannon diversity index (B) and Pielou evenness $(\mathrm{C})$ in the sacred forests. 


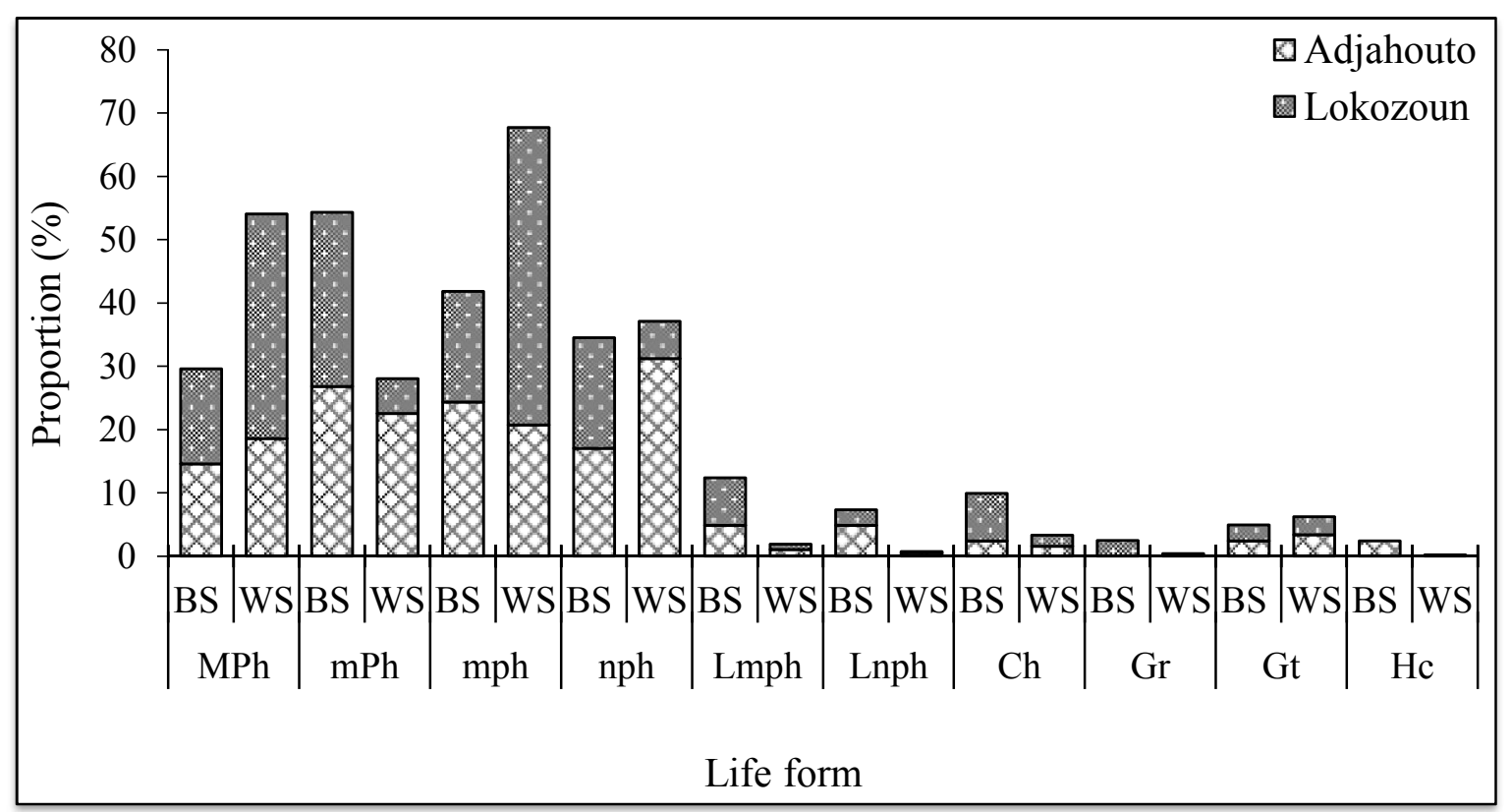

MPh : Megaphanerophytes, mPh : Mesophanerophytes, mph : Microphanerophytes, nph : Nanophanerophytes, Lmph : Mesophanerophytes lianas, Lnph : Nanophanerophytes lianas, Ch : Chamaephytes, Gr: Rizomatous Geophytes, Gt : Tuberous Geophytes, Hc : Hemicryptophytes

Figure 3: Abundance (BS) and Cover (WS) of life form proportion in the Adjahouto and Lokozoun sacred forests.

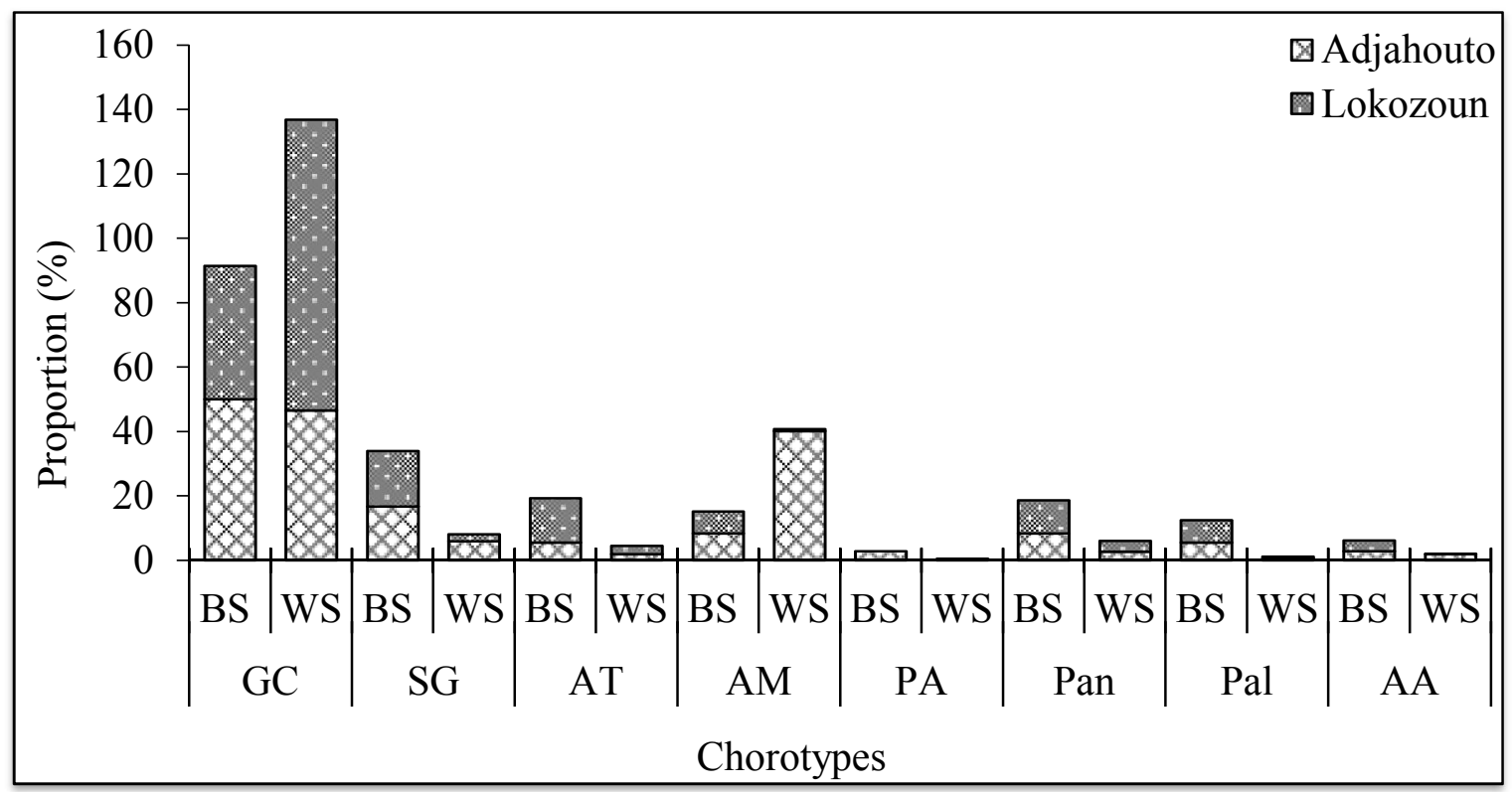

GC: Guineo-Congolese, SG: Sudano-Guinean, AT: Afro-tropical, AM: Afro-Malagasy, PA: African Pluri-regional, Pan: Pantropical, Pal: Paleotropical, AA: Afro-american

Figure 4: Abundance (BS) and Cover (WS) of chorotypes proportion in the Adjahouto and Lokozoun sacred forests. 

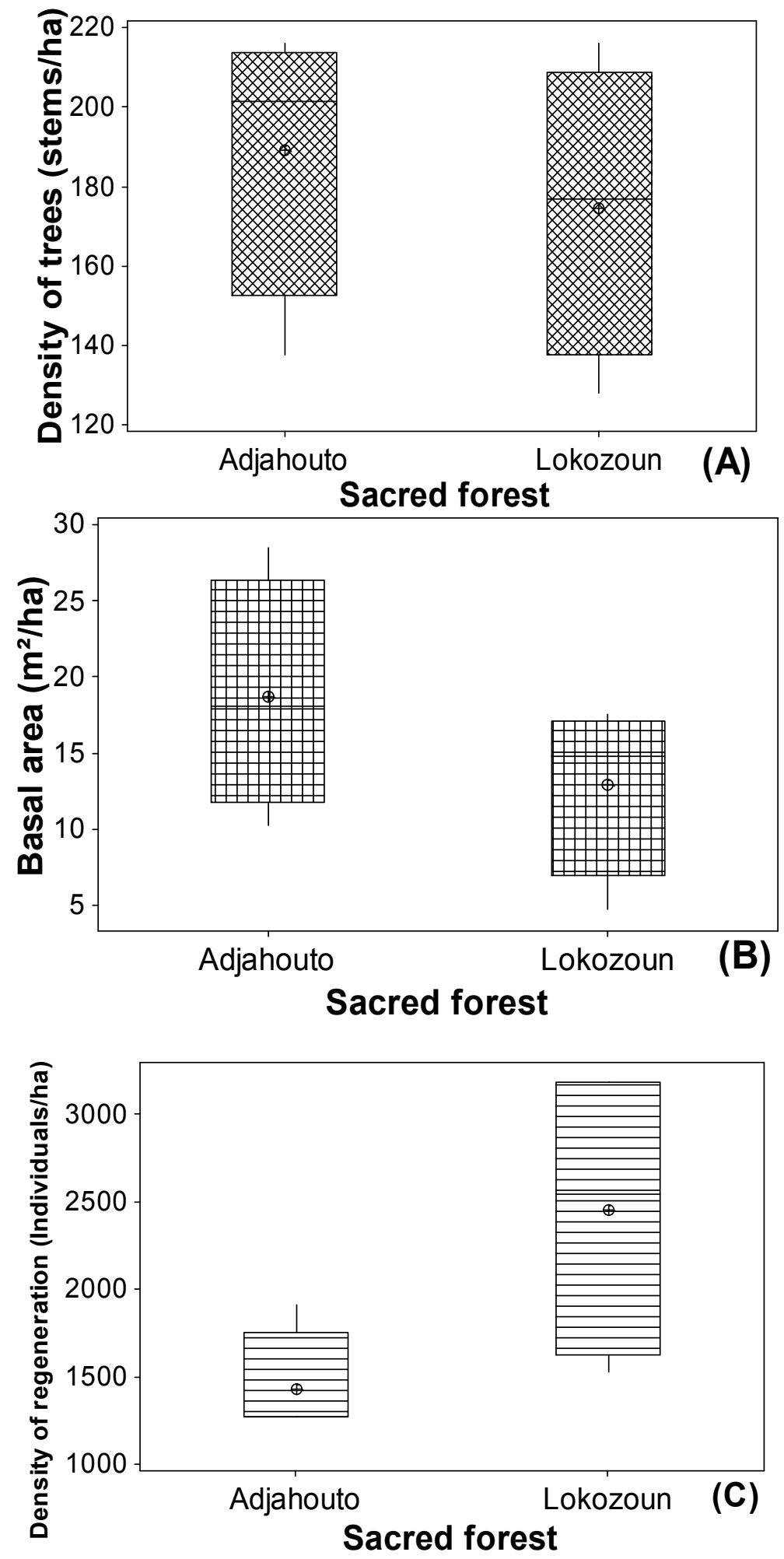

Figure 5: Variation of tree density (A), basal area (B) and density of regeneration (C) in the sacred forests. 
Table 2: List of rare species identified in Benin in the sacred forests.

\begin{tabular}{|c|c|c|c|c|}
\hline Species & Plant family & $\begin{array}{l}\text { Status in } \\
\text { Benin }\end{array}$ & $\begin{array}{l}\text { Sacred forest } \\
\text { Adjahouto }\end{array}$ & $\begin{array}{l}\text { Sacred forest } \\
\text { Lokozoun }\end{array}$ \\
\hline $\begin{array}{l}\text { Albizia ferruginea (Guill. and Perr.) } \\
\text { Benth. }\end{array}$ & Fabaceae & $\mathrm{VU}$ & 0 & 1 \\
\hline Caesalpinia bonduc (L) Roxb & Fabaceae & EW & 0 & 1 \\
\hline Carissa spinarum $\mathrm{L}$. & Apocynaceae & EN & 1 & 0 \\
\hline Celtis mildbraedii Engl. & Celtidaceae & EN & 0 & 1 \\
\hline Khaya senegalensis (Desv.) A. Juss. & Meliaceae & EN & 0 & 1 \\
\hline Milicia excelsa (Welw.) Berg & Moraceae & $\mathrm{EN}$ & 1 & 1 \\
\hline Rauvolfia vomitoria Afzel. & Apocynaceae & EN & 1 & 0 \\
\hline Terminalia superba Engl. and Diels & Combretaceae & $\mathrm{EN}$ & 0 & 1 \\
\hline Triplochiton scleroxylon K. Schum. & Sterculiaceae & EN & 0 & 1 \\
\hline $\begin{array}{l}\text { Zanthoxylum zanthoxyloides (Lam.) } \\
\text { Zepernick and Timber }\end{array}$ & Rutaceae & $\mathrm{EN}$ & 1 & 1 \\
\hline
\end{tabular}

$E N:$ endangered $; V U:$ vulnerable $; E W:$ extinct in the wild $; 1:$ present $; 0:$ absent

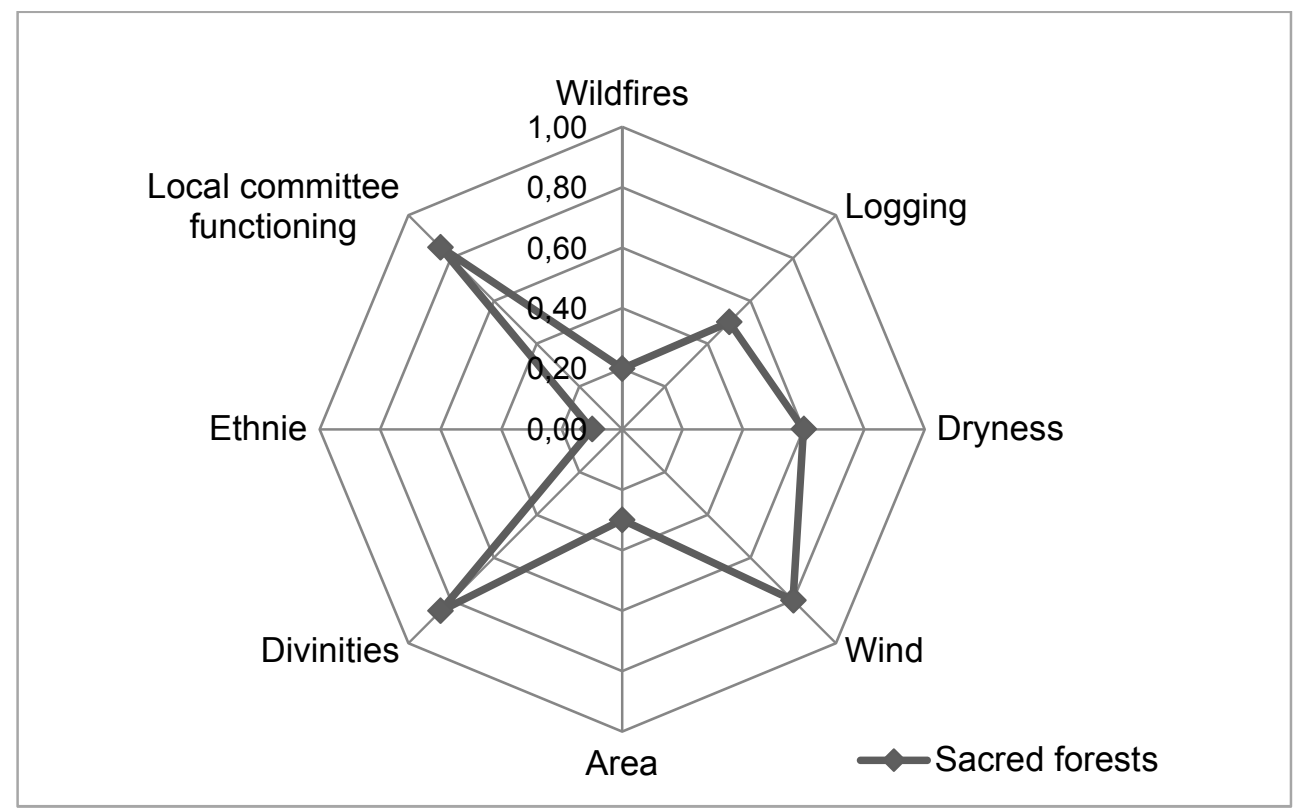

Figure 6: Local communities' perception of the determinants of sacred forests degradation. 


\section{DISCUSSION}

Sacred forest diversity, structural parameters and biodiversity conservation

In this study, we measured the contribution of sacred forests to phytodiversity conservation through plant community diversity and tree population structural parameters analysis. Shannon diversity index varied from 2.64 to 3.26 bits in the two sacred forests. In the gazetted forest of Pahou located in the same phytogeographical region and ecological conditions as the sacred forests of Ajahouto and Lokozoun, Arouna et al. (2017) obtained Shannon diversity index values ranging from 1.60 to 2.36 bits. According to Arouna et al. (2017), tree density and basal area in Pahou gazetted forest varied respectively from 284 to $406 \mathrm{stems} / \mathrm{ha}$ and from 8.41 to $16.21 \mathrm{~m}^{2} / \mathrm{ha}$. In the studied forests, tree density and basal area varied from 174.47 to 189.22 stems/ha and 12.93 to 18.70 $\mathrm{m}^{2} /$ ha. The high density observed in the gazetted forests compared to the sacred forests can be explained by the illegal anthropogenic perturbation which involves permanent reconstitution of the forests and then high tree density but with low diameter (Arouna et al., 2017). This in turn explains the high basal area observed in the sacred forests which shelter many trees with big diameter size. These results showed that sacred forests locally contribute more to the conservation of biodiversity than the gazetted forests.

The plant diversity of Adjahouto and Lokozoun sacred forests showed that most primary forest plant species were presents in these forests. A comparison of the plant species diversity in these sacred forests with gazetted forests in the same phytogeographic region harboring no deity showed a clear deterioration of gazetted forests (Bete and Toko, 2011; Toko Imorou et al., 2015; Djogbenou et al., 2016; Arouna et al., 2017). Protecting sacred forests is the result of multiple sequential rites that have the power to deter negative anthropogenic actions on biodiversity such as agriculture, hunting, gathering, fishing (Ibo, 2005).
However, apart from the sacred aspects and divinities present in the two investigated sacred forests, it is also important to highlight other factors that recently contribute to the conservation of these sacred forests although the current anthropogenic pressure in the region. In fact, the two sacred forests are delimited by tree planted lines and benefited of plant enrichment with technical and financial support of the "Local forests management support project (PAGEFCOM)" since 2007. Despite the rapid land cover change in the region, the conservation of these two sacred forests can be also explained by the support received from PAGEFCOM and the management committees installed by the project which contribute to preserve these relic forests.

The contribution of Adjahouto and Lokozoun sacred forests to biodiversity conservation in southern Benin is noteworthy. These sacred forests are islands or relics of ancient forests (semi-deciduous, dense dry forest, woodland, gallery forest) that previously covered much part of South and Centre of Benin (Akoegninou, 2001; Toko Imorou et al., 2015). They are home to an exceptional biological diversity and shelter many threatened species in Benin. These sacred forests function then as real pools and sanctuaries of biodiversity since they host many plant species which are listed on the Red List of Benin of Endangered Species (Neuenschwander et al., 2011). Some of these endangered species have a high rate of natural regeneration in these two sacred forests. Therefore, these forests represent important living gene bank that can be used for the restoration of other degraded sites with the same ecological potentialities.

\section{Community perception of sacred forests conservation}

Our results demonstrated that the main factors contributing to the sacred forests conservation were the functioning of the sacred forest local committee, the types of divinities and wind. The functioning of the committees is also recognized as a factor 
determining the conservation of protected areas by Djogbénou (2010). According to the common mystical beliefs, the land ownership in sacred forests is dedicated to spiritual powers which are either spirits or deities. The same observations were made by Boukpessi (2010) and Bete and Toko (2011) in the sacred forests of the Centre of Togo and in South Benin respectively. For Malan (2009) and Fournier (2011), the sacralization of the sites represents an effective strategy for natural resources conservation because the ritual practices in the sacred forests influence positively biodiversity conservation. Sacred forests appear as excellent refuges for many threatened species. They are traditionally managed and protected for cultural and religious purposes. Cultural rules and socioreligious considerations contribute to the sustainable protection of many species in a given region and therefore enhance conservation of biological diversity. Several authors also reported the importance of traditional rules in the conservation of biodiversity (Ago, 2000; Bete and Toko, 2011; Savadogo et al., 2011; Ehinnou Koutchika et al., 2013; Ehinnou Koutchika et al., 2014b). Sacred forests are places of prayer, blessings and offerings to the deities to ask for peace and victory in difficult times as shown by Boukpessi (2010) in the study of indigenous practices of biodiversity conservation in the Centre of Togo. According to Akouehou (2004), the sacred forest is also home to some agreements between men and the ancestors' spirits. The sacred forests emerge then as a place for an exchange of goods, prayers, sacrifices from men against graces, rewards and gods protection. Access to sacred forests by the uninitiated is subject to the authorization of the dignitaries and sometimes requires offerings (palm wine, chickens, cola nuts, sheep, etc.) to deities. The fear of the sacred by the people promotes their respect and ensures their preservation.

Nowadays, it is remarkable to note that sacred forests are facing to threats due not only to the demography pressure but to the extent of monotheistic religions which demystify traditional practices and believes which previously help to protect the forests. This could lead in near future to the degradation and extinction of important natural resources which may not be replaceable.

\section{Conclusion}

Our study demonstrates that Adjahouto and Lokozoun sacred forests are both representative samples of natural ecosystems which in the past were widespread in the southern part of Benin. These sacred forests still shelter many threatened species of high value and can be represented as hotspots of biodiversity in the region. The forests conservation is under the deities' dignitaries who, through endogenous rules (traditional laws), work for the forests protection and conservation. These forests contribute at local and national scale for the conservation of plant species and other genetic resources.

Measures for conservation of these ecosystems must be developed and implemented in agreement with local stakeholders. These measures must begin by stopping activities that degrade the sacred forests and the constant presence of the forestry administration for the forest protection.

\section{COMPETING INTERESTS}

The authors declare that they have no competing interests.

\section{AUTHORS' CONTRIBUTIONS}

ITI and OA initiated the research proposal, collected the primary data and contributed to the first draft manuscript writing. LGH conducted population survey and processed to data analysis with the support of ITI. BS supervised the process of data collection and analysis. All authors read and approved the final manuscript.

\section{REFERENCES}

Adam S, Boko M. 1983. Le Bénin. SodimasEdicef : Paris ; 95p. 
Ago E. 2000. Sacralisation et niveau de maturation des forêts denses semidécidues du plateau d'Adja au Sud-ouest $\mathrm{du}$ Bénin. Diplôme d'Ingénieur Agronome. FSA/UNB, Abomey-Calavi, Bénin, $137 \mathrm{p}$ +annexes.

Akobundu I, Agyakwa CW. 1989. Guide des Adventices d'Afrique de l'Ouest. IITA: Ibadan, Nigéria ; $522 \mathrm{p}$.

Akoegninou A, Houndagba JC, Tossou MG, Essou J-P, Akpagana K. 2001. La végétation d'une zone de transition entre la forêt dense humide semi-décidue et les savanes: la région de Bantè (Bénin, Afrique de l'Ouest). J. Bot. Soc. Bot. Fr., 15: 99-108. DOI: 10.1080/00378941.1878.10827912.

Akoegninou A, Van der Burg WJ, Van der Maesen LJG. 2006. Flore Analytique $d u$ Bénin. Backhuys Publishers: Wageningen University; 1034 p.

Akouehou GS. 2004. Environnement institutionnel et gestion traditionnelle des espaces forestiers : cas de la région des Monts Kouffé au Centre du Bénin. Les Cahiers d'Outre-Mer [En ligne], 226227 | Avril-Septembre 2004, mis en ligne le 13 février 2008, consulté le 15 octobre 2015. URL: http://com.revues.org/526; DOI : $10.4000 /$ com.526.

Amoussou E, Totin Vodounon SH, Hougni A, Vissin EW, Houndenou C, Mahe G, Boko M. 2016. Changements environnementaux et vulnérabilité des écosystèmes dans le bassin-versant béninois du fleuve Niger. Int. J. Biol. Chem. Sci., 10(5): 2183-2201. DOI : http://dx.doi.org/10.4314/ijbcs.v10i5.20.

Arbonnier M. 2002. Arbres, Arbustes et Lianes des Zones Sèches d'Afrique de l'Ouest. CIRAD-MNHN : Paris, France ; $574 \mathrm{p}$.

Arouna O, Toko Imorou I, Gibigaye M, Allé P, Tenté B. 2017. Analyse comparative de l'état de conservation des forêts classées, des forêts communautaires et des forêts sacrées au Sud-Bénin (Afrique de l'Ouest). International Journal of Innovation and Applied Studies, 19(1):
123-139. URL: http://www.issrjournals.org/.

Arouna O, Toko I, Djogbenou CP, Sinsin B. 2011. Comparative analysis of local populations' perceptions of socioeconomic determinants of vegetation degradation in soudano-guinean area in Benin (West Africa). International Journal of Biodiversity and Conservation, 3(7): 327-337. DOI: 10.5897/IJBC.

Bete SS, Toko II. 2011. Evaluation de la contribution des Forêts Sacrées à la conservation de la biodiversité végétale du Sud Bénin. Rapport d'étude, Projet d'Appui à la Gestion des Forêts Communales, Cotonou, Bénin, 54 p + annexe.

Boukpessi T. 2010. Les pratiques endogènes de conservation de la biodiversité au Centre-Togo. Thèse de doctorat unique en Géographie. Université de Lomé 280 p + Annexes. de Souza S. 2008. Flore du Bénin: Nom des Plantes dans les Langues Nationales Béninoises. Tome 3, Deuxième édition : Cotonou, Bénin ; 680 p.

Diatta CS, Diouf M, Karibuhoye C, Sow AA. 2017. Sites naturels sacrés et conservation des ressources marines et côtières en milieu traditionnel diola (Sénégal). Revue d'Ethnoécologie. DOI : 10.4000/ethnoecologie.3264.

Djego J, Djego-Djossou S, Cakpo Y, Agnani P, Sinsin B. 2011. Evaluation du potentiel ethnobotanique des populations rurales au Sud et au centre du Bénin. Int. J. Biol. Chem. Sci., 5(4): 1432-1447. DOI: http://dx.doi.org/10.4314/ijbcs.v5i4.10.

Djogbenou CP, Toko Imorou I, Arouna O, Sinsin B. 2016. Caractérisation des groupements végétaux des forêts sacrées du Centre et du Sud du Bénin. Afrique SCIENCE, 12(2): 54 - 66. URL : http://www.afriquescience.info.

Djogbenou CP, Arouna O, Toko Imorou I, Sinsin B. 2011. Analyse comparative des profils des plans d'aménagement 
participatifs des forêts classées au Bénin. Revue Sciences Environnementales de Université de Lomé (Togo), 7 : 51-79.

Djogbénou CP. 2010. Analyse multicritère des Plans d'Aménagement et de Gestion participatifs des forêts classées au Bénin: développement d'un modèle durable. Thèse de Doctorat, Université d'Abomey-Calavi, 226 p.

Ehinnou Koutchika IR, Salako KV, Agbani OP, Chougourou CD, Sinsin B. 2014a. Étude écologique et diversité des bois sacrés des Communes de Glazoué- SavèOuessè au Bénin. Journal of Animal \& Plant Sciences, 21(3): 3313-3323. URL: http://m.elewa.org/Journals/about-japs/

Ehinnou Koutchika IR, Adjakpa B J, Tenté AB, Agbani P, Mensah S, Chougourou CD, Sinsin B. 2014b. Savoirs locaux et conservation de la biodiversité dans les bois sacrés du centre Bénin en Afrique de l'ouest. Rev. Sc. Env. Univ., Lomé (Togo), 11 : 563-728.

Ehinnou Koutchika RI, Agbani PO, Sinsin B. 2013. Influence des perturbations anthropiques sur la biodiversité des bois sacrés du Centre Bénin. Int. J. Biol. Chem. Sci., 7(1) : 306-318.

FAO. 2010. Evaluation des ressources forestières mondiales. Rapport national du Bénin. Département des forêts. Rome, Italie, $28 \mathrm{p}$.

Fournier A. 2011. Consequences of wooded shrine rituals on vegetation conservation in West Africa: a case study from the Bwaba cultural area (west Burkina Faso). Biodiversity and Conservation, 20(9): 1895-1910. DOI: doi.org/10.1007/s10531-017-1492-8.

Glele Kakaï R, Sinsin B. 2009. Structural description of two Isoberlinia dominated vegetation types in the Wari-Maro Forest Reserve (Benin). South Africa Journal of Botany, 75: 43-51. URL: https://www.journals.elsevier.com/southafrican-journal-of-botany.

Hutchinson J, Dalziel JM. 1954-1972. Flora of West Tropical Africa. Crown Agents for Overseas Governments and
Administrations, Londres, vol. 1 à 3: Vol. 1, tomes 1 and 2, 828 p., Vol. 2, 544 p., Vol. 3, tomes 1 and 2, 852 p.

Ibo J. 2005. Contribution des organisations non gouvernementales écologistes à l'aménagement des forêts sacrées en Côte d'Ivoire : l'expérience de la croix verte. VertigO-La revue en sciences de l'environnement, 6(1) : 93-106. DOI : 10.4000 /vertigo.

Kokou K, Adjossou K, Hamberger K. 2005. Les forêts sacrées de l'aire Ouatchi au sud-est du Togo et les contraintes actuelles des modes de gestion locale des ressources forestières. VertigO - La revue en sciences de l'environnement, 6(3) : 1-10. DOI : 10.4000/vertigo.

Kokou K, Sokpon N. 2006. Les forêts sacrées du couloir du Dahomey. Bois et Forêts des Tropiques, 288(2) : 15-23.

Kouholi CO. 2012. Contribution des forêts sacrées à la conservation de la phytodiversité dans la Commune de Ouaké (République du Bénin). Mémoire de Licence professionnelle : EPAC/UAC ; 56 p.

Lebrun JP, Stock AL. 1991-1997. Enumérations des Plantes à Fleurs d'Afrique Tropicale (Vol. I-IV). Editions des Conser. Et Jard. Bot.: Genève.

Magurran AE. 2004. Measuring Ecological Diversity. Blackwell publishing: Malden, Oxford, Carlton, USA, UK, Australia; $256 \mathrm{p}$.

Malan FD. 2009. Religion traditionnelle et gestion durable des ressources floristiques en Côte d'Ivoire : le cas des Ehotilé, riverains du Parc National des Îles Ehotilé. VertigO - La revue en sciences de l'environnement, 9(2). DOI : 10.4000/vertigo.

Neuenschwander P, Sinsin B, Goergen G. 2011. Protection de la nature en Afrique de l'Ouest. Une Liste Rouge pour le Bénin. International Institute of Tropical Agriculture (IITA): Cotonou, Bénin; $265 \mathrm{p}$.

OIBT. 2012. Etude pour la restauration et la gestion durable des Forêts sacrées des 
sites Ramsar 1017 et 1018 du Bénin. Cotonou, Bénin, 26 p.

Pielou E.C. 1969. An Introduction to Mathematical Ecology. Wiley: New York; 294p.

PIFSAP. 2012. Potentiel en diversité biologique de 24 forêts sacrées des Départements de l'Ouémé et du Plateau au Bénin. Cotonou, Bénin, 135 p.

Raunkiaer C. 1934. The Life Forms of Plants and Statistical Plant Geography. Clarendron Press: Oxford; 632 p.

Savadogo S, Ouedraogo A, Thiombiano A. 2011. Diversité et enjeux de conservation des bois sacrés en société Mossi (Burkina Faso) face aux mutations socioculturelles actuelles. Int. J. Biol. Chem. Sci., 5(4): 1639-1658. DOI: http://dx.doi.org/10.4314/ijbcs.v5i4.27

Shannon CE, Weaver W. 1949. The Mathematical Theory of Communication. Univ. Illinois Press: Urbana, Chicago III; $125 \mathrm{p}$.

Sinsin B, Kassa B, Kidjo F. 2010. Réseau des aires protégées du Bénin. In Atlas de la Biodiversité de l'Afrique de l'Ouest (Tome I), Sinsin B, Kampmann D (eds). Bénin \& Frankfurt/Main: Cotonou; 522529.

Sokpon N, Agbo V. 1999. Sacred groves as tools for indigenous forest management in Benin. Annales des Sciences Agronomiques Univ. Nat du Bénin, 1 : 162-175.

Sokpon N, Ago E. 2001. Sacralisation et niveau de maturation des forêts denses- décidues du plateau d'Adja au Sud-Ouest du Bénin. J. Rech. Sci. Univ. Lomé (Togo), 5(2) : 319-331.

Sokpon N, Agbo V. 2010. Forêts sacrées et patrimoine au Bénin. In Atlas de la Biodiversité de l'Afrique de l'Ouest (Tome 1, Volume 1), Sinsin B, Kampmann D (eds). Cotonou and Frankfurt/Main. ISBN 978-3-9813933-09, pp. 536-547.

Toko Imorou I, Djogbenou CP, Arouna O, Sogbossi SE, Sinsin B. 2015. Effets de la taille et des régions phytogéographiques sur la diversité floristique et la structure des forêts sacrées au Bénin. Annales des Sciences Agronomiques (Bénin), 19(1): 79-97.

Toko I. 2008. Etude de la variabilité spatiale de la biomasse herbacée, de la phénologie et de la structure de la végétation le long des toposéquences $d u$ bassin supérieur du fleuve Ouémé au Bénin. Thèse de Doctorat, Université d'Abomey-Calavi, Bénin, $241 \mathrm{p}$.

Weber HE, Moravec J, Theurillat J-P. 2000. International code of phytosociological nomenclature (3rd edn). Journal of Vegetation Science, 11 : 739-768. DOI : $10.1111 /$ jvs.

White F. 1986. La végétation de l'Afrique: Mémoire Accompagnant la Carte de la Végétation de l'Afrique. ORSTOM : Paris; 384 p. 